\title{
A Three-Fold Classification of Tight Gas Based Primarily on Dynamic Relationship Between Gas Charging History and Reservoir Tightening Process and its Application
}

\author{
Lei Zhang ${ }^{1,2,3,}$, Lunwei Zhu ${ }^{1,3}$, Jianian Shen ${ }^{1,3}$ and Qifei Huang ${ }^{2}$
}

\begin{abstract}
${ }^{1}$ Geoscience College, Northeast Petroleum University, Daqing, Heilongjiang, 163318, China; ${ }^{2}$ Department of Geology and Geophysics, Texas A\&M University, College Station, TX, 77840, USA; ${ }^{3}$ Accumulation and Development of Unconventional Oil and Gas, State Key Laboratory Cultivation Base Jointly constructed by Heilongjiang Province and the Ministry of Science and Technology, Northeast Petroleum University, Daqing, Heilongjiang, 163318, China
\end{abstract}

\begin{abstract}
Building upon the foundation of the prior investigations, a three-fold classification of tight gas reservoirs is proposed in this paper which is based primarily on dynamic relationship between gas charging history and reservoir tightening process, coupled with tectonic evolution, source-reservoir relationship, migration and charging pattern. The three categories of tight gas are: (1) "pre-existing" basin-centered gas reservoir, in which the reservoir sands experienced earlystage tightening processes, occurring before peak gas generation, expulsion from source rock, and charging of reservoir; (2) "pre-existing subsequent-improved" tight gas reservoir, in which the reservoir sands were also tightened before gas charging and then underwent reservoirs improvement mainly caused by the tectonic activities; and (3) "subsequentconventional" tight gas reservoir where reserved sands were tightened after the peak of gas generation, expulsion from source rock, and charging of reservoir. This type of tight gas initially formed conventional gas accumulation during gas charging of reservoir, and subsequently modified to tight gas reservoir. All the three categories of tight gas have different geological conditions of gas accumulation and gas accumulation patterns, which can be used as characteristics to classify these tight gas systems, and thus have distinctive control on regional gas distribution. The results of applying this tight gas classification for an actual basin show that correctly distinguishing these three kinds of tight gas reservoirs from each other could contribute greatly to the exploration and development of tight gas reservoirs.
\end{abstract}

Keywords: Classification, dynamic relationship, gas charging history, reservoir tightening process, tight gas.

\section{INTRODUCTION}

The increasing demand for energy in the world has made it imperative to explore for and exploit unconventional oil and gas resources. Tight gas systems, of which tight gas accumulations are products, are potentially one of the more economically important, unconventional gas resources in the world [1], and have attracted considerable industry attention and now become a focus area of global unconventional gas exploration. In the United States, a large-scale commercial production has been achieved from tight gas systems, and contributed as much as $26 \%$ of the total annual gas production in 2010; the tight gas resources in China have got rapid progress in exploration and development recently, with a series of significant breakthroughs in the Erdos basin and Sichuan basin and subsequent discoveries in the Tarim basin, Tuha basin, Songliao basin and several other basins, and has become the most realistic, economically important unconventional gas resources for a long time in the future $[2,3]$.

Classification of tight gas reservoirs has been one of the current issues in tight gas research field. The concept of

*Address correspondence to this author at the Daqing high-tech industrial development zone No.199, Daqing, Heilongjiang province, China; Zip code: 163318; Tel: 0459-6503868; E-mail: zhlkeyan@163.com "deep basin gas" [4] included the earliest classification of tight sandstone gas reservoir based on a gas accumulation model and stimulated further discussion on the classification of such reservoirs [1, 3, 5-9]. Law [1] subsequently suggested that this type of gas accumulations should be called as "basin-centered gas accumulation", and divided it into two types: direct type and indirect type, in term of the organic matter types in source rocks. He also pointed out that widely used term "tight gas sands" may include gas accumulations that are trapped as conventional, buoyant accumulations. It implied that there are two types tight gas accumulation: basin-centered gas accumulation and conventional tight gas accumulation. However, Shanley [5] proposed clearly that low-permeability reservoirs from the Greater Green River basin of southwest Wyoming are not part of a continuoustype gas accumulation or a basin-center gas system in which productivity is dependent on the development of enigmatic sweet spots. Instead, gas fields occur in low-permeability, poor-quality reservoir rocks in conventional traps. Hereafter, various classifications were proposed from different viewpoints by different workers. Although these various classifications have different viewpoints and use different definitions, all of them acknowledge two types of tight sandstone gas reservoirs: basin-centered gas reservoir and conventional tight sandstone gas reservoir. Among these classifications, "pre-exiting deep gas" [6], "pre-exiting deep gas accumula- 
tion" [7], "reservoir-tightening before gas-charging tight gas" [8], and "continuous-type tight gas" [9] are equivalent to basin-centered gas reservoir; meanwhile, "subsequent tight sand gas" [6], "subsequent tight sand gas accumulation" [7], "reservoir-tightening after gas-charging tight gas" [8], "trap-type tight gas" [9] and so on belong to conventional tight gas reservoirs. The primary objective of this paper is to propose a new, more detailed and easy-identified classification of tight gas, according to the most critical control on tight gas accumulation patterns. Furthermore, we also provide an example, by applying this tight gas classification to Denglouku formation, through two sides of the Central Faulted-uplift Zone of northern Songliao basin in China, to show how useful it is in exploration and development of tight gas reservoirs.

\section{TIGHT SANDSTONE AND CLASSIFICATION OF TIGHT GAS}

\subsection{Definition of Tight Sandstone}

Several sets of criteria for classifying tight sandstone exist. The most common criterion is based on original in place permeability (in-situ condition) where it is less than $0.1 \times 10^{-3}$ $\mu \mathrm{m}^{2}[2,10-13]$. The original in place permeability is generally equivalent to air permeability under normal pressure $0.5-1.0 \times 10^{-3} \mu^{2}$, which corresponds to a tight sandstone porosity of $7-12 \%$ [14]. In this study, we adopt the criteria for tight sandstone reservoir classification as follows: porosity less than $12 \%$, original in-place permeability less than $0.1 \times 10^{-3} \mu \mathrm{m}^{2}$, and air permeability less than $1 \times 10^{-3} \mu \mathrm{m}^{2}[2$, 11]. If these criteria are met, we define the reservoir as tight sandstone.

\subsection{Classification of Tight Sand Gas}

Based on previous researches, we consider that the most critical control on tight gas accumulation patterns is dynamic relationship between gas charging history and reservoir tightening process [6]. The best way to characterize tight gas accumulation from the standpoint of gas accumulation mechanism, processes and patterns is to study the dynamic relationship between peak gas generation and expulsion, gas charging, and reservoir tightening, coupled with tectonic evolution, source-reservoir relationship, migration and charging pattern. Based on this principle, we propose a tight gas classification which divided tight gas reservoirs into three types: "pre-existing" basin-centered gas reservoir, "preexisting subsequent-improved" tight gas reservoir, and "subsequent-conventional" tight sandstone gas reservoir.

(1) "Pre-existing" basin-centered gas reservoir is similar to "pre-exiting deep gas" [6] and "pre-exiting deep gas accumulation" [7]. The term "pre-exiting" refers to reservoir sands experienced early-stage tightening processes, which result in a porosity less than $12 \%$ and air permeability less than $1 \times 10^{-3} \mu^{2}$, occurring before peak gas generation, expulsion from source rock, and charging of reservoir. Driving by the pressure caused by compaction and gas generation and expansion, gas overcame the capillary pressure and hydrostatic pressure and widely expelled the pore water in tight reservoirs with a short distance migration. Finally, it forms a dynamic trap gas res- ervoir in the status of mechanical equilibrium and mass balance, which generally lacks downdip water contacts and buoyancy is not a significant factor for gas migration. This type of tight sand gas reservoirs is mainly developed in the deeper parts of depressions, middle of synclines, or in the downdip part of the slopes of the basins and is not controlled by structural traps. Gas accumulation requires that reservoirs are in close physical proximity to source rocks or are self-sourcing. The closer the reservoir is to the source rock, the more gas accumulation. The best scenario occurs when the reservoir is in direct contact with, or interbedded in the source rock [6]. The distribution of "pre-existing" basin-centered gas reservoirs is controlled by the superimposed areas of source rock and tight sand reservoir.

(2) "Pre-existing subsequent-improved" tight gas reservoir. "Pre-existing" also means that the reservoir sands were tightened before peak gas generation, expulsion from source rock, and charging of reservoir, as same as "preexisting" basin-centered gas reservoir. However, reservoirs are commonly far away from source rocks, instead of in close physical proximity to source rocks. As a result, there are no sufficient effects on gas migration by compaction and gas generation and expansion, and it is difficult for gas to expel pore water away and charge into tight reservoirs by buoyancy alone. Under such conditions, gas accumulations generally occur in fracture zones within these tight reservoirs, which is caused by the subsequent tectonic activities and improved reservoir quality, so called "subsequent-improved". Thus, the distribution of this type of tight gas reservoirs is mainly controlled by fracture zones formed during later tectonic events. The secondary gas reservoirs, in which gas has been adjusted from former "pre-existing" basin-centered gas reservoirs and "subsequentconventional" tight sandstone gas reservoirs into earlyformed tight reservoirs improved by later tectonic activities, should be attributed to "pre-existing subsequent-improved" tight gas reservoirs.

(3) "Subsequent-conventional" tight sandstone gas reservoir. The term "subsequent" indicates that the tight reservoirs are formed after the peak of gas generation, expulsion from source rock, and charging of reservoir. At the peak of gas generation and expulsion, reservoir sands were not tightened, and gas migrated via buoyancy, tectonic force, and hydrodynamic pressure along the predominant migration pathways. This formed conventional gas accumulations which have normal gas-water contact. Subsequently, the reservoir underwent tightening by diagenesis or tectonic compression. The critical period for gas accumulation lasts from the peak of gas generation to the tightening of reservoir rock. The gas accumulation mechanism is something similar to conventional gas reservoirs, so-called "conventional", in which reservoirs can be either close to or far away from the source rock and have predominant migration pathways from source rock to reservoirs. The gas accumulation of this type of tight sandstone gas reservoir is highly influenced by conventional structural traps, stratigraphic traps, and lithologic traps; most are trapped around high structural positions 
such as paleo-uplifts and paleo-traps. Thus, the extents of gas distribution can be as large, but do not exceed the extents of the traps $[6,7]$.

\section{APPLICATION OF TIGHT GAS CLASSIFICATION IN TIGHT GAS EXPLORATION AND DEVELOP- MENT}

\subsection{Regional Geologic Setting of Study Area}

The Songliao basin is a large Mesozoic-Cenozoic nonmarine sedimentary basin in the northeastern China, which is $750 \mathrm{~km}$ long, 330 to $370 \mathrm{~km}$ wide and has a total area of $26 \times 10^{4} \mathrm{~km}^{2}$. In reverse geologic age, the Upper Jurassic Huoshiling formation $\left(\mathrm{J}_{3} \mathrm{~h}\right)$, Lower Crataceous Shahezi formation $\left(\mathrm{K}_{1} \mathrm{sh}\right)$, Yingcheng formation $\left(\mathrm{K}_{1} \mathrm{yc}\right)$, Denglouku formation $\left(\mathrm{K}_{1} \mathrm{~d}\right)$, Quantou formation $\left(\mathrm{K}_{1} \mathrm{q}\right)$, Upper Crataceous Qingshankou formation $\left(\mathrm{K}_{2} \mathrm{qn}\right)$, Yaojia formation $\left(\mathrm{K}_{2} \mathrm{y}\right)$, Nenjiang formation $\left(\mathrm{K}_{2} \mathrm{n}\right)$, Sifangtai formation $\left(\mathrm{K}_{2} \mathrm{~s}\right)$, Mingshui formation $\left(\mathrm{K}_{2} \mathrm{~m}\right)$ and Cenozoic strata were developed. The deep layer of Songliao basin generally refers to the rifting-stage formations and the lower part of the depression stage formations, aged older than the 2 nd member of the Quantou formation [15]. In this work, we focus on the area through the two sides of the Central Faulted-uplift Zone, which is separated by the Central Faulted-uplift Zone to two regions, named the Xujiaweizi and Gulong regions (Fig. 1). The Xujiaweizi region is located to the east of the Central Faulted-uplift Zone, mainly within the Xujiaweizi Rift. The Xujiaweizi region extends predominantly in the North-South direction of a distance of $80 \mathrm{~km}$, as wide as 40 $\mathrm{km}$ in the central area, for a total area of about $5350 \mathrm{~km}^{2}$. The Gulong region is located in the west of the Central Faulted-uplift Zone and it covers three second-order tectonic units: the Gulong Rift, Changjiaweizi Rift and Daqing Faulted-terrace Belt. The main part is located in the Gulong and Changjiaweizi Rift with a strike of NNE and areal extent of approximately $8190 \mathrm{~km}^{2}$. The Denglouku formation is developed during the transition from the rifting stage to depression stage [16]. The range of sedimentary facies of the Denglouku formation in study area include: alluvial fan, fan delta, braided river delta, shallow water delta, fluvial, lacustrine, sub-lacustrine fan, and underwater gravity flow $[17,18]$, which formed diverse types of reservoir rock.

\subsection{Tightening Processes of Sandstone Reservoirs}

Analysis of the diagenesis stage [19] and the plot of porosity versus depth of the sandstone samples from Denglouku formation (Fig. 2) show that: when the sandstone reservoir of Denglouku formation was buried around $1000 \mathrm{~m}$ (during early diagenetic stage B, at the end of earlycementation), it underwent an initial tightening process, which is defined when the porosity of some samples begin to fall under $12 \%$ [6], with the porosity of reservoir reduced greatly by early-compaction and early-cementation; hereafter sandstone reservoir entered the early-dissolution and began to form secondary pore, but the compaction and cementation were still the predominant actions of sandstone reservoir causing gradual reduction of porosity against burial depth; when the burial depth reached about $1700 \mathrm{~m}$, during intermediate diagenetic stage $A_{2}$, sandstone reservoir was almost completely tightened and went in the middle- dissolution with a slowly gradual reducing of porosity; along with further enhanced dissolution, sandstone reservoir entered late-strong- dissolution and formed a strong secondary porosity zone from depth range $2400 \mathrm{~m}$ (intermediate diagenetic stage $B_{1}$ ) to about $2900 \mathrm{~m}$ (intermediate diagenetic stage $\mathrm{B}_{2}$ ), at the end of late-strong-dissolution, below which cementation enhanced relatively due to weakened dissolution and the reservoir was completely tightened again.

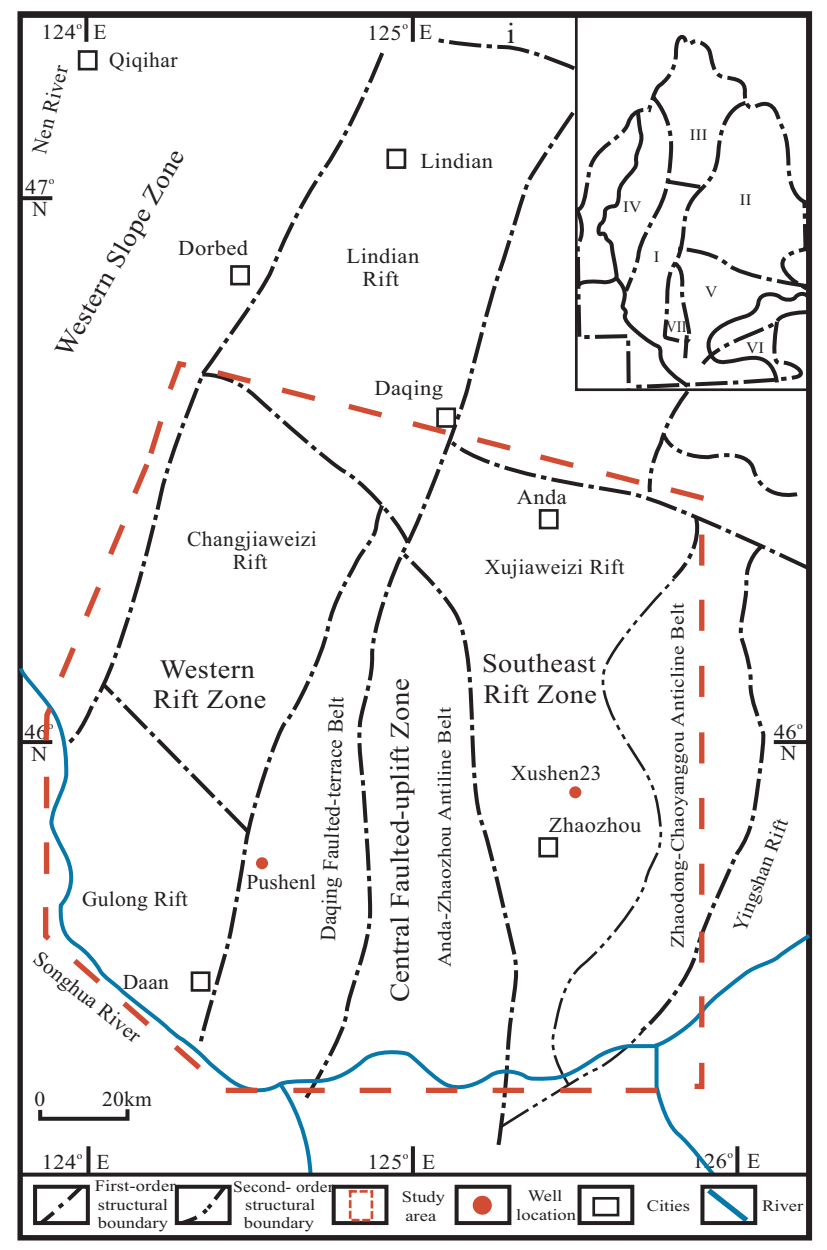

Fig. (1). Location map of the study area showing the major structural divisions referred to in the text (I. Western Rift Zone; II. Northeast Faulted-uplift Zone; III. Northern Slope Zone; IV. Western Slope Zone; V. Southeast Rift Zone; VI. Southeast Uplift Zone; VII. Central Faulted-uplift Zone).

In the Xujiaweizi region, sandstone reservoirs of the Denglouku formation began the initial tightening process during the middle depositional period of the Quantou formation and completely tightened during the early depositional period of the Yaojia formation. Following the first completely tightening of the reservoirs, secondary porosities began to form. From the late depositional period of the Nenjiang formation, the sand reservoirs were completely tightened again (Fig. 3a). In the Gulong region, sandstone reservoirs of Denglouku formation began tightening from the early depositional period of the Quantou formation and completely tightened between the late depositional period of the Quantou formation and the early deposition period of 
the Qingshankou formation (Fig. 3b). It must be mentioned that due to the lack of data at shallow depth in the Gulong region, the upper part of the porosity against depth plot was plotted using the data from the Xujiaweizi region as reference. From this hypothesized porosity evolution trend line, it is predicted that the entire tightening process of the Denglouku reservoirs in the Gulong region may have occurred earlier than that in the Xujiaweizi region (hypothesized dashed red line in Fig. (2). Additionally, even though sandstone reservoirs of Denglouku formation in the Gulong region experienced the development of secondary porosity, the porosities are generally less than $12 \%$ during this stage. Thus, we estimate that the sandstone reservoirs of Denglouku formation in the Gulong region may have completely tightened during the middle depositional period of the Quantou formation (hypothesized dashed red line in Fig. (3b).

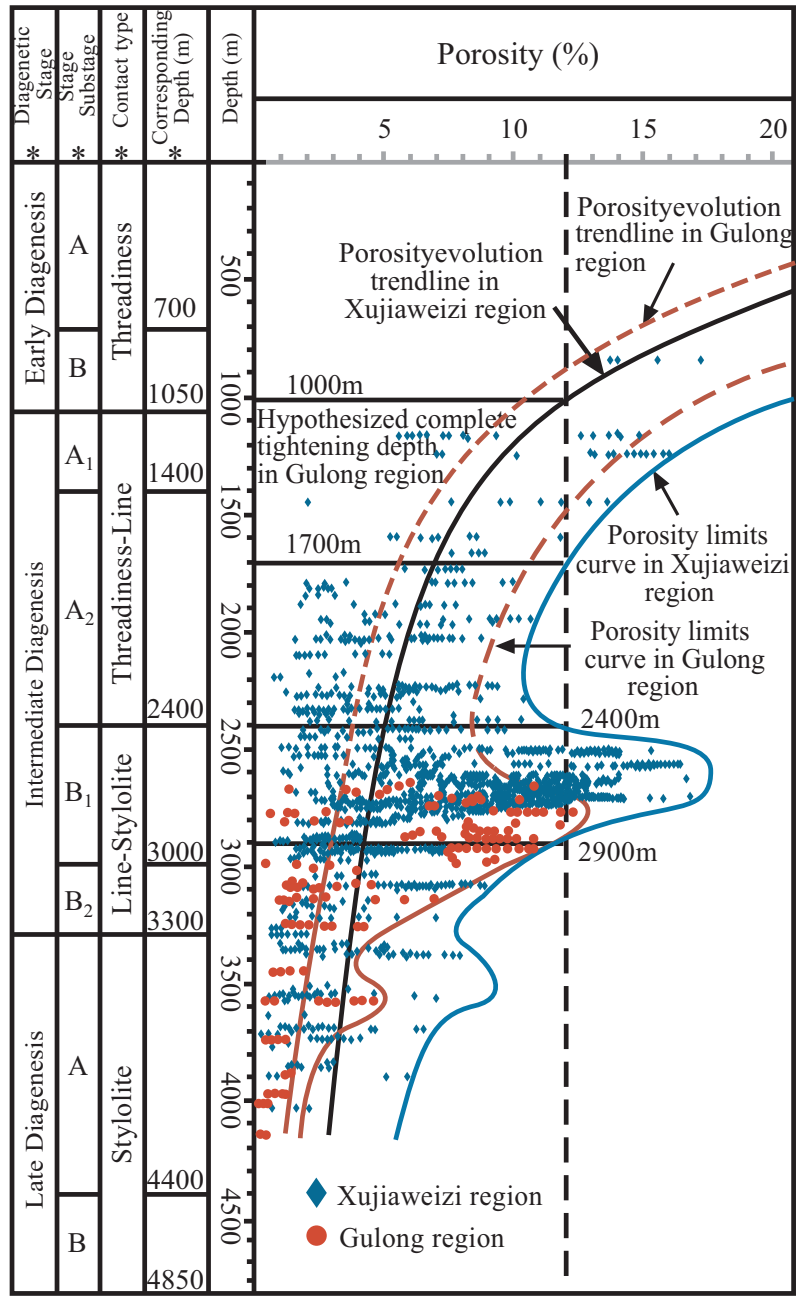

Fig. (2). Relationship between empirical porosity of Denglouku reservoir sands and burial depth.

\subsection{Gas Generation and Expulsion History of Source Rocks}

Most of the natural gas in the Denglouku reservoirs is generated from the source rocks developed during the rifting stage or those in the Denglouku formation, mainly dark mudstone of the 2 nd member in the formation $\left(\mathrm{K}_{1} \mathrm{~d}^{2}\right)$ [20].

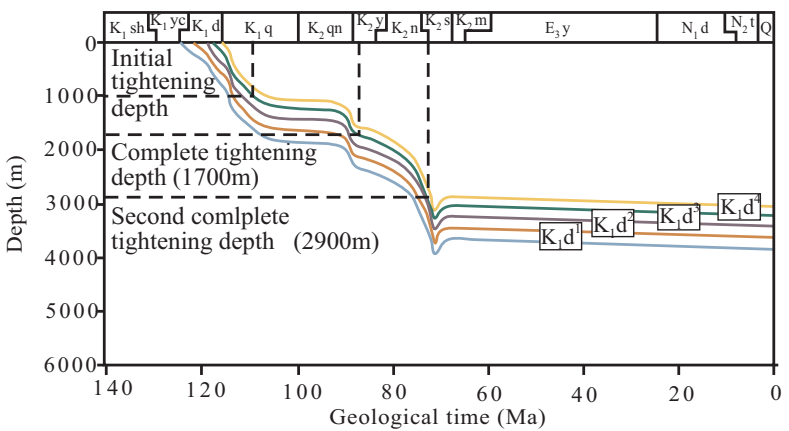

(a) Well Xushen23

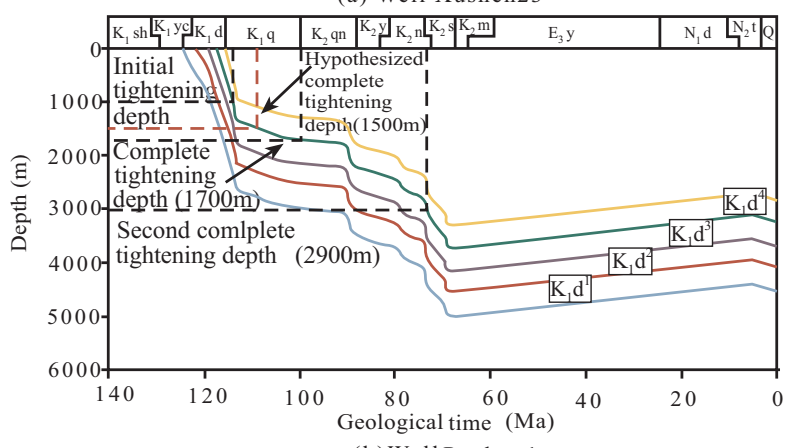

(b) Well Pushen 1

Fig. (3). Denglouku formation burial history chart of well Xushen23 and well Pushen1.

The rifting-stage gas source rock is of high quality [20, 21]. In the Xujiaweizi region, rifting-stage source rock has high gas generation rate (Fig. 4) and began to generate gas at a high rate during the depositional period of the Denglouku formation. Peak gas generation lasted from the late depositional period of the Quantou formation to the late depositional period of the Qingshankou formation and generation rate reduced significantly afterwards [21] (Fig. 5a). In contrast, gas generation rate is lower in the Gulong region (Fig. 4). Gas source rocks began increasing gas generation during the late depositional period of the Yingcheng formation and reached peak gas generation at the early depositional period of the Quantou formation. Then gas generation rate gradually reduced after the early depositional period of the Yaojia formation (Fig. 5a).

The dark mudstone source rock of the $\mathrm{K}_{1} \mathrm{~d}^{2}$ formation is of poor to medium quality [22]. In the Gulong region, the dark mudstone of the $\mathrm{K}_{1} \mathrm{~d}^{2}$ is uniformly distributed and has relatively high gas generation rates. In the Xujiaweizi region, the $\mathrm{K}_{1} \mathrm{~d}^{2}$ formation shows limited development of dark mudstone source rock, which results in a very low gas generation rate (Fig. 4). $\mathrm{K}_{1} \mathrm{~d}^{2}$ source rock began to generate gas rapidly during the late depositional period of the Quantou formation. Two gas generation peaks occurred, one during the depositional period of the Quantou formation to the Qingshankou formation and the second during the Nengjiang formation deposition. A significant amount of gas was generated during the deposition period of the Nengjiang formation, and the source rocks sustained a moderately high gas generation rate afterwards (Fig. 5b). This sustained period of late gas generation in the $\mathrm{K}_{1} \mathrm{~d}^{2}$ source rock is advantageous for the accumulation of natural gas [22]. 


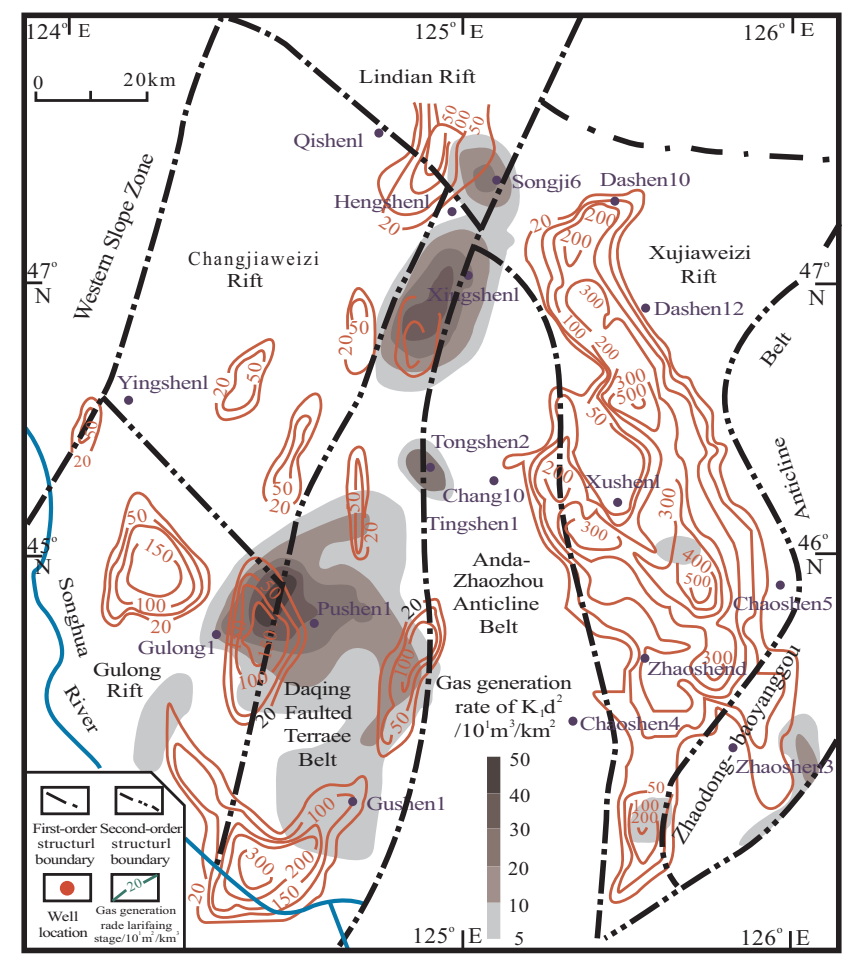

Fig. (4). Thickness and gas generation rate of rifting-stage and $\mathrm{K}_{1} \mathrm{~d}^{2}$ source rock in study area.

\subsection{Conditions for Gas Migration}

There are three types predominantly oil and gas migration pathway in sedimentary basins: faults, unconformities and permeable formations [23]. In the Xujiaoweizi region, the rifting-stage source rocks are far away from Denglouku tight reservoirs and have good contact with the migratory pathway faults which act as the dominant vertical migration pathway for natural gas to Denglouku formation; the unconformities are the dominant pathways for lateral migration of gas; and Denglouku sandstone cannot serve as the lateral migration pathway itself, and therefore should be combined with migratory pathway faults and unconformities for effective gas migration [24]. In the Gulong region, poor contact between the rifting-stage source rock and the migratory faults restricts the movement of gas from the source rock to the Denglouku reservoir; much of the sandstone are developed within the gas generation area of $\mathrm{K}_{1} \mathrm{~d}^{2}$ source rock and are interbedded within or in direct contact with the source rock, which is advantageous for widespread, short distance migration of gas within the sand to expel the in-situ water and accumulate in the reservoir. Thus, the Denglouku sandstones act as the dominant gas migration pathway from $\mathrm{K}_{1} \mathrm{~d}^{2}$ source rock to Denglouku sandstone reservoir [22].

\subsection{Tight Gas Types: Identification and Significance for Gas Exploration and Development}

Through analysis and comparison of the gas generation and expulsion histories and reservoir tightening processes, along with the studies of fault activities [25], we are able to identify the different types of tight gas reservoirs and their dominant controls on gas distribution in Denglouku formation through two sides of the Central Faulted-uplift Zone of northern Songliao basin.

In the Xujiaweizi region, the Denglouku reservoir sands were tightened after peak gas generation, gas expulsion from source rock, and the resulting charging of the reservoir. The peak gas generation of rifting-stage source rock is during the late depositional period of the Quantou formation to the late depositional period of the Qingshankou formation. At the same time, this region is also experiencing an active faulting stage lasting from the late depositional period of the Quantou formation to the middle depositional period of the Qingshankou formation; this faulting period is crucial for migration of the generated gas to the reservoirs. However, the sandstone of the Denglouku formation was not completely tightened until the early depositional period of the Yaojiazu formation (Fig. 6a). This type of tight sand gas is defined as typical "subsequent-conventional" tight gas reservoir, for which gas accumulation mechanism is similar to conventional gas reservoirs. Thus, in the Xujiaweizi region, the best locations for gas accumulation in the Denglouku formation are high fracture-density zones or successive paleo-uplifts and paleo-traps near the migratory pathway faults, within and closely around an area defined by the extents of gas generation [20,24]. This conclusion agrees with findings from previous gas exploration of Denglouku formation in the Xujiaweizi region. Therefore, it is suggested that the next step in gas exploration should focus on these areas.

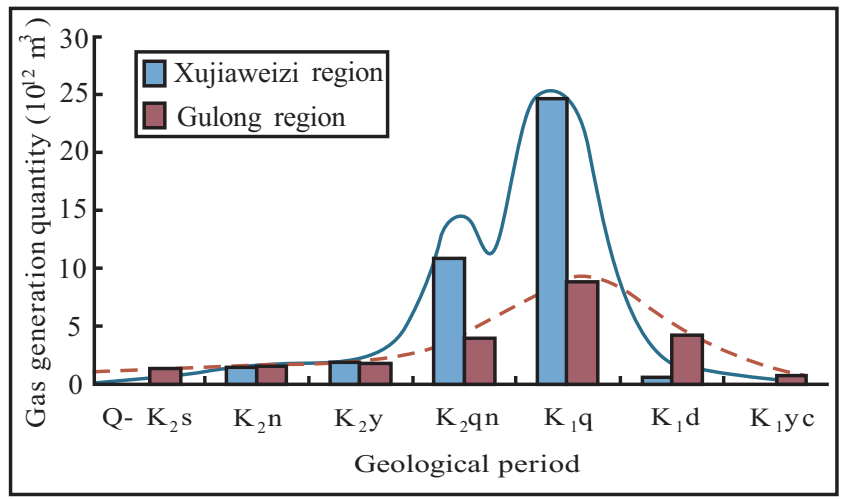

(a) Rifting-stage source rock

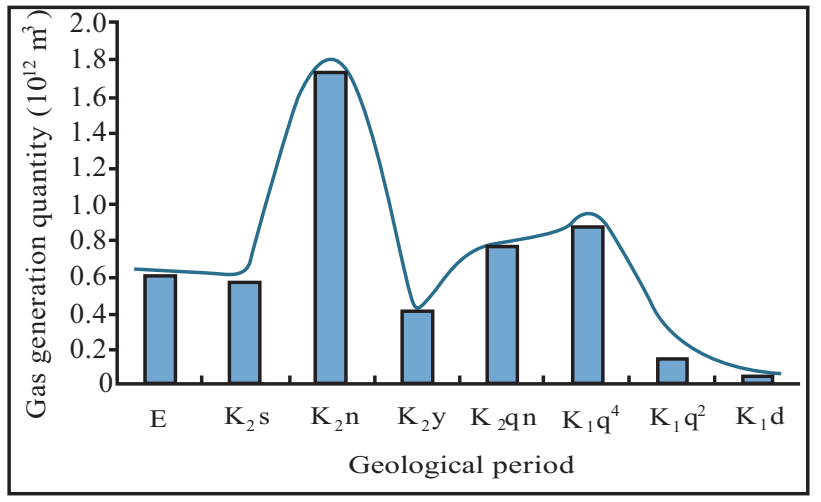

(b) $\mathrm{K}_{1} \mathrm{~d}^{2}$ source rock

Fig. (5). Histogram displaying gas generation quantities of source rocks in different geological periods. 


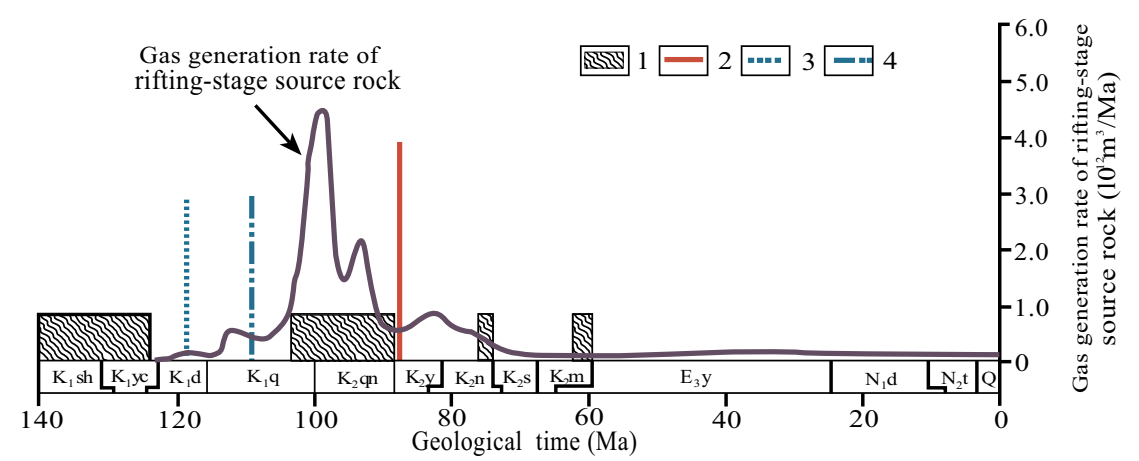

(a) Xujiaweizi region

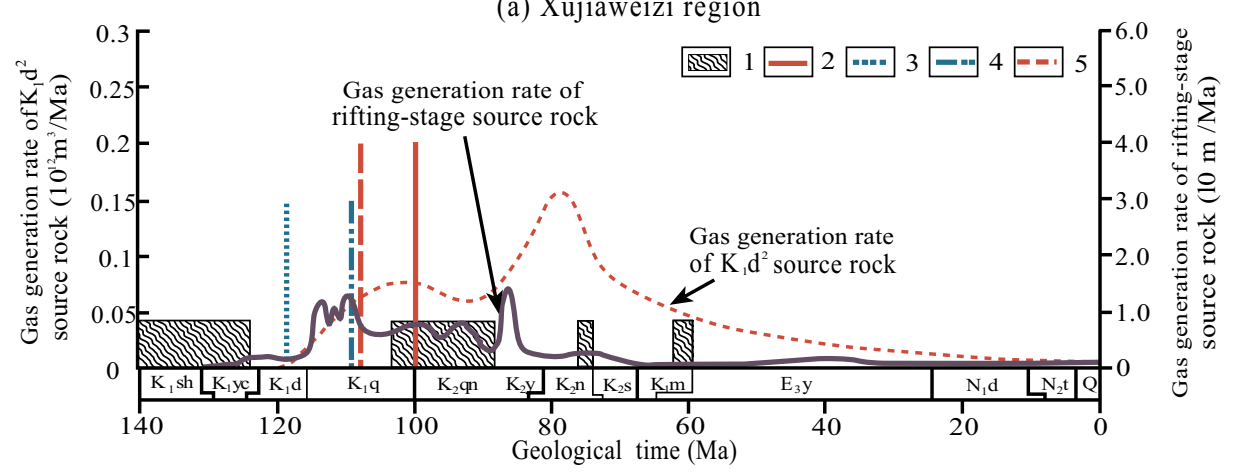

(b) Gulong region

Fig. (6). Relationship between Donglouku reservoir tightening, periods of intense fault activities, and gas generation histories of source rocks in study area (1. Period of intense fault activities; 2 . Complete tightening period of reservoirs; 3 . Sealing capability forming period of $\mathrm{K}_{1} \mathrm{~d}^{2}$ seal rock; 4. Sealing capability forming period of $\mathrm{K}_{1} \mathrm{q}^{1+2}$ seal rock; 5. Hypothesized complete tightening period of reservoirs).

On the other hand, in the Gulong region, the Denglouku reservoir sands were tightened prior to the peak gas generation, expulsion from $\mathrm{K}_{1} \mathrm{~d}^{2}$ source rock, and charging of reservoir (Fig. 6b). The $\mathrm{K}_{1} \mathrm{~d}^{2}$ source rocks and reservoirs are interbedded and widely distributed, both having developed in the deeper parts of depressions or in the downdip parts of the slope in the basin [22]. This tends to form "pre-existing" basin-centered gas reservoirs, in which gas distribution is predominantly controlled by the superimposed areas of $\mathrm{K}_{1} \mathrm{~d}^{2}$ source rock and tight sand reservoir. Migration of natural gas from the rifting-stage source rock predominantly occurred during the period of intense fault activities from the late depositional period of the Quantou formation to the middle depositional period of the Qingshankou formation. At this point in time, the Denglouku sand reservoirs are almost completely tightened (Fig. 6b). Poor contact between the rifting-stage source rock and the migratory faults restricts the movement of gas from the source rock to the Denglouku reservoir. These factors make it difficult to form the "subsequent-conventional" tight sand gas reservoirs, like those in the Xujiaweizi region. Also, as the reservoirs have been modified weakly due to stable tectonic setting, it is difficult to form the "pre-existing subsequent-improved" tight gas reservoir type in Denglouku formation. From these observations, it is clear that natural gas from the rifting-stage gas source rock cannot effectively accumulate and form into large gas plays. To conclude, the key areas to focus the next steps of natural gas exploration in the area should be within and closely around the effective gas generation extent of $\mathrm{K}_{1} \mathrm{~d}^{2}$ source rock, and the key formations for exploration should be $K_{1} \mathrm{~d}^{2}$ and adjacent formations.

\section{CONCLUSION}

(1) According to the dynamic relationship between gas charging history and reservoir tightening process, coupled with tectonic evolution, tight gas reservoirs can be classified into three types: "pre-existing" basin-centered gas reservoir, "pre-existing subsequent-improved" tight gas reservoir, and "subsequent-conventional" tight gas. Each type has different gas accumulation geological conditions and gas accumulation patterns, and thus has distinctive control in regional gas distribution.

(2) Different types of tight gas plays exist in the Denglouku formation through two sides of the Central Faulted-uplift Zone, and these differences play a key role in controlling the regional gas distribution. In the Xujiaweizi region, the Denglouku formation is dominated by the "subsequent-conventional" tight sand gas reservoir. Most of the natural gas accumulation occurs within and closely around an area defined by the extents of gas generation from the rifting-stage source rock, in the high fracturedensity zones and successive paleo-uplifts and paleotraps near the migratory pathway faults. In the Gulong region, "pre-existing" basin-centered gas reservoir, in which reservoir sands were tightened prior to gas charging, tends to be formed near the developed area of source rock in $\mathrm{K}_{1} \mathrm{~d}^{2}$ formation. Natural gas distribution is predominantly controlled by overlapping areas of $\mathrm{K}_{1} \mathrm{~d}^{2}$ source rock and the tight sand reservoir.

(3) The clear understanding for the different types of tight sandstone gas in the Denglouku formation of the Xujiaweizi and Gulong regions and their controls on re- 
gional gas distribution shows that correctly distinguished tight gas reservoirs types, by using this three-fold classification, could contribute greatly to the exploration and development of tight gas reservoirs all over the world.

\section{CONFLICT OF INTEREST}

The authors confirm that this article content has no conflict of interest.

\section{ACKNOWLEDGEMENTS}

This research is supported by the Scientific and Technological Research General Project of Heilongjiang Provincial Education Department (12521061).

\section{REFERENCES}

[1] B. E. Law, "Basin-centered gas systems", AAPG Bulletin, vol. 86, pp. 1891-1919, 2002.

[2] C. N. Zou, S. Z. Tao, X. X. Zhang, D. B. He, C. M. Zhou, and X. H. Gao, "Geologic characteristics, controlling factors and hydrocarbon accumulation mechanisms of China's Large Gas Provinces of low porosity and permeability", Science in China Series D: Earth Sciences, vol. 39, pp. 1607-1624, 2009.

[3] J. Z. Li, B. C. Guo, M. Zheng, and T. Yang, "Main types, geological features and resource potential of tight sandstone gas in China", Natural Gas Geoscience, vol. 23, pp. 607-615, August 2012.

[4] J. A. Masters, "Deep basin gas trap, Western Canada ", $A A P G$ Bulletin, vol. 63, pp. 152-181, 1979.

[5] K. Shanley, R. M. Cluff, and J. W. Robinson, "Factors controlling prolific gas production from low-permeability sandstone reservoirs: implications for resource assessment, prospect development and risk analysis", AAPG Bulletin, vol. 88, pp. 1083-1121, 2004.

[6] Z. X. Jiang, S. G. Lin, X. Q. Pang, and J. Wang, "The comparison of two types of tight sand gas reservoir", Petroleum Geology and Experiment, vol. 28, pp. 210-214, 2006.

[7] X. X. Dong, L. F. Mei, and Y. W. Quan, "Types of tight sand accumulation and its exploration prospect", Natural Gas Geoscience, vol. 18, pp. 351-355, 2007.

[8] J. S. Davis, I. Belien, X. Liu, and S. Dougherty. "Modeling gas migration, distribution, and saturation in a structurally and petrologically evolving tight gas reservoir", In: International Petroleum Technology Conference, 2011.

[9] J. X. Dai, Y. Y. Ni, and X. Q. Wu, "Tight gas in china and its significance in exploration and exploitation", Petroleum Exploration and Development, vol. 39, pp. 257-264, 2012.

[10] C. W. Spencer, "Geologic aspects of tight gas reservoirs in the Rocky Mountain region", Journal of Petroleum Geology, vol. 37, pp. 1308-1314, 1985.

[11] R. C. Surdam, "A new paradigm for gas exploration in anomalously pressured tight gas sands, in the rocky mountain laramide basins", In AAPG Memoir 67: Seals, traps, and the petroleum system, Tulsa: AAPG, 1997.

[12] S. A. Holditch, "Tight gas sands", Journal of Petroleum Technology, vol. 58, pp. 86-93, 2006.

[13] National Energy Administration, SY/T 6832 -2011. Oil and gas industry standard of the People's Republic of China, Beijing: Petroleum Industry Publishing House, 2011.

[14] X. H. Ma, A. L. Jia, J. Tan and D. B. He, "Tight sand gas development technologies and practices in China", Petroleum Exploration and Development, vol. 39, pp. 572-579, 2012.

[15] H. S. Qiao, C. L. Fang, and J. Y. Niu, Petroleum Geology to the Deep Layers in Eastern China, Beijing: Petroleum Industry Press, 2002.

[16] F. Z. Qiang, J. C. Zao, X. X. Nong, Z. Shun, F. Z. Hui, and T. A. Cross, "Tectonostratigraphic units and stratigraphic sequences of the nonmarine Songliao basin, northeast China", Basin Research, vol. 22, no. 1, pp. 79-95, 2010.

[17] S. Z. Ma, L. Q. Gan, C. L. Nie, Y. H. Zhang, and L. Cong, "Sedimentary Facies Analysis of Denglouku Formation in Xujiaweizi Area", Geological Science and Technology Information, vol. 32, pp. 1-6, July 2013.

[18] X. J. Zhang, L. Zhang, Q. Yang, S. F Lu, and Z. Yang, "The coupling relationship between sedimentary and tectonic evolution in the denglouku formation in gulong area of northern songliao basin", Chinese Journal of Geology, vol. 47, pp. 1162-1175, 2012.

[19] Y. L. Meng, A. W. Hu, D. W. Qiao, F. X. Xi, X. Pan, J. W. Wang, and W. C. Tian, "Regional diagenetic law and control of diagenesis over gas-bearing capacity of tight reservoirs in deep xujiaweizi fault depression, songliao basin", Acta Geologica Sinica, vol.86, pp. 325-334, 2012.

[20] Y. G. Ren, D. F. Zhu, and C. B. Wan, "Natural gas accumulation rule of xujiaweizi depression in songliao basin and future exploration target", Petroleum Geology and Oilfield Development in Daqing, vol.23, pp. 26-29, 2004.

[21] L. H. Xu, S. F. Lu, J. F. Chen, G. Ma, L. Li, and J. Li, "Gasgeneration evaluation of deep hydrocarb on source rocks in $\mathrm{Xu}$ jiaweizi fault depression", Acta Petrolei Sinica, vol. 29, pp. 846$852,2008$.

[22] L. Zhang, X. J. Zhang, S. F. Lu, and Z. Yang, "Possibility of formation of deep basin gas reservoirs in the denglouku formation of gulong-changjiaweizi region, northern songliao basin", Oil and Gas Geology, vol. 34, pp. 441-449, 2013.

[23] F. Ghisetti, and L. Uezzani, "Detachments and normal faulting in the Marche fold-and-thrust belt (central Apennines, Italy): inference fluid migration paths", Journal of Geodynamics, vol. 29, pp. 345-369, 2000.

[24] G. Fu, M. Hu, and Y. Han, "Controlling of faults to gas accumulation of volcanic rock in depression basin: an example from $\mathrm{xu}-$ jiaweizi depression of songliao basin", Journal of Jilin University (Earth Science Edition), vol.42, pp. 1-8, 2012.

[25] X. M. Sun, S. Q. Wang, Y. D. Wang, J. Y. Du and Q. W. Xu, "The structural feature and evolutionary series in the northern segment of Tancheng-Lujiang fault zone", Acta Petrologica Sinica, vol.26, pp.165-176, 2010.

This is an open access article licensed under the terms of the Creative Commons Attribution Non-Commercial License (http://creativecommons.org/licenses/by-nc/3.0/) which permits unrestricted, non-commercial use, distribution and reproduction in any medium, provided the work is properly cited. 